\title{
Pengaruh Sinbiotik Kefir Tepung Pisang Batu (Musa balbisiana) terhadap Kadar Kolesterol Total dan Kadar Trigliserida Tikus Model Sindrom Metabolik
}

\author{
Diana Martha Ariesta Sari', Taufik Maryusman ${ }^{2}$, Santi Herlina ${ }^{3}$ \\ ${ }^{1,2}$ Program Studi S-1 Ilmu Gizi, Universitas Pembangunan Nasional "Veteran” Jakarta, Jakarta, \\ Indonesia email: dianamarthaas@gmail.com,pembelajartaufik@gmail.com \\ ${ }^{3}$ Program Studi S-1 Keperawatan, Universitas Pembangunan Nasional "Veteran” Jakarta, Jakarta, \\ Indonesia email: santiherlina@upnvj.ac.id
}

\begin{abstract}
This study was conducted to analyze the effects of banana (Musa balbisiana) flour kefir synbiotic on total cholesterol level and triglyceride level of Metabolic Syndrome rats model. This research used a true experimental method with pre-post test control group design. The number of 24 rats model were randomly divided into four groups, i.e. K- (healthy rats, standard diet), K+ (Metabolic Syndrome rats, standard diet), PI (Metabolic Syndrome rats, standard diet and synbiotic 1,8 ml/200grBW/day), and PII (Metabolic Syndrome rats, standard diet and synbiotic 3,6 ml/200grBW/day), with intervention duration of 3 weeks. Blood draws were carried out at the beginning and end session of the intervention to analyze total cholesterol and triglyceride levels. The data from the measurement of total cholesterol and triglyceride levels before and after the intervention were then analyzed using the Paired T-Test. The results of the Paired T-Test showed differences $(p<0,05)$ in total cholesterol and triglyceride levels before and after intervention in all groups. The banana flour kefir synbiotic has been shown to reduce cholesterol and triglyceride levels in rats.
\end{abstract}

Keyword: Synbiotic, kefir, Musa balbisiana, cholesterol, triglyceride

\begin{abstract}
Abstrak
Penelitian ini dilakukan untuk menganalisis pengaruh sinbiotik kefir tepung pisang batu terhadap kadar kolesterol total dan kadar trigliserida tikus model sindrom metabolik. Desain penelitian ini eksperimental murni dengan pre-post test control group design. Sebanyak 24 tikus Sprague dawley jantan dibagi secara acak menjadi empat kelompok, yaitu $\mathrm{K}$ - (tikus sehat, pakan standar), $\mathrm{K}+$ (tikus sindrom metabolik, pakan standar), PI (tikus sindrom metabolik, pakan standar dan sinbiotik $1,8 \mathrm{ml} / 200 \mathrm{gr} \mathrm{BB}$ tikus/hari), dan PII (tikus sindrom metabolik, pakan standar dan sinbiotik 3,6 ml/200gr BB tikus/hari) dengan intervensi 3 minggu. Pengambilan darah dilakukan pada awal dan akhir intervensi untuk menganalisis kadar kolesterol total dan trigliserida. Kadar kolesterol total dan trigliserida sebelum dan setelah intervensi dianalisis dengan uji Paired T-Test. Hasil penelitian menunjukkan bahwa terdapat perbedaan nyata $(\mathrm{p}<0,05)$ kadar kolesterol total dan kadar trigliserida sebelum dan setelah intervensi pada semua kelompok. Sinbiotik kefir tepung pisang batu terbukti mampu menurunkan kadar kolesterol dan trigliserida tikus.
\end{abstract}

Kata Kunci: Sinbiotik, kefir, pisang batu (Musa balbisiana), kolesterol, trigliserida 


\section{PENDAHULUAN}

Sindrom metabolik merupakan masalah kesehatan utama di dunia yang meningkatkan risiko terjadinya diabetes mellitus tipe 2 (Mukaromah \& Susilowati, 2021), penyakit kardiovaskuler, dan kematian (Mazidi, Pennathur, \& Afshinnia, 2017). Pada penelitian Nova \& Yanti (2017) dengan 146 responden didapatkan sekitar 44,5\% mengalami obesitas, sedangkan pada penelitian populasi orang bekerja didapatkan nilai kolesterol yang cukup tinggi yaitu sebesar 52,2\% (Syagata, 2019) yang beresiko nantinya kepada penyakit kardiovaskuler. International Diabetes Federation (IDF) memperkirakan sekitar 25\% populasi (Nolan et al., 2017) atau lebih dari satu miliar orang di dunia mengalami sindrom metabolik (Saklayen, 2018). Di Indonesia, hasil penelitin menunjukkan 28,4\% penduduk di Kota Jakarta mengalami sindrom metabolik (Soewondo et al. 2010).

Komponen sindrom metabolik meliputi obesitas sentral, tekanan darah tinggi, gangguan toleransi glukosa, dan dislipidemia (Chen et al., 2018). Dislipidemia merupakan kelainan metabolisme lipid yang menyebabkan peningkatan secara persisten dari konsentrasi kolesterol dan trigliserida plasma (Zhang et al., 2018), yang selanjutnya dapat menginduksi terjadinya penyakit kardiovaskuler aterosklerotik (Blesso \& Fernandez, 2018; Singh \& Singh, 2016). Hal ini dapat dicegah dengan pengaturan kadar lipid darah yang efektif (Chen et al., 2018), yaitu salah satunya dengan mengkonsumsi kombinasi dari probiotik dan prebiotik (Octavia, Djamiatun, $\&$ Suci, 2017).

Probiotik dilaporkan dapat mengurangi kadar kolesterol total dan kadar trigliserida pada hewan coba (Wu et al., 2017). Mekanisme penurunan lipid oleh probiotik dilakukan dengan mengasimilasi kolesterol (Razmpoosh et al., 2019), mengurangi sirkulasi enterohepatik, dan memproduksi Short Chain Fatty Acid (SCFA) (Cho \& Kim, 2015), serta menurunkan sintesis asam lemak di hati (Weitkunat et al., 2015). Produk minuman fermentasi yang berpotensi sebagai sumber probiotik adalah kefir (Bourrie et al. 2016).

Kefir merupakan minuman susu fermentasi dengan kandungan ragi (Bourrie et al., 2016) yang membentuk simbiosis bermanfaat bersama bakteri (Carasi et al., 2015). Kefir dapat diproduksi dengan bahan baku susu kambing (Rosa et al., 2017). Susu kambing dipilih karena memiliki potensi alergi yang lebih rendah (García et al., 2014), memiliki kecernaan yang lebih tinggi, serta mengandung jumlah asam lemak rantai menengah dan pendek yang lebih tinggi dibandingkan dengan susu sapi (Ahmed et al. 2015). Penelitian menunjukkan bahwa konsumsi harian produk kefir susu kambing dan turunannya memiliki efek hipokolesterolemia yang signifikan (Pimenta et al., 2018).

Prebiotik seperti Fructo-oligosaccharides (FOS) dan inulin dapat membantu dalam menurunkan kadar lipid (Cahyani, 2017), karena difermentasi oleh bakteri dalam 
kolon sehingga menghasilkan SCFA (McLoughlin et al., 2017). FOS dan inulin tersebut dapat ditemukan di dalam pisang (Hardisari \& Amaliawati, 2016). Salah satu jenis pisang yang belum dimanfaatkan dengan optimal adalah pisang batu (Musa balbisiana) (Musita, 2014).

Pisang batu (Musa balbisiana) mengandung pati resisten yang relatif tinggi (39,35\%), dimana pati resisten ini juga memiliki efek prebiotik (Musita, 2014). Prebiotik dapat meningkatkan viskositas usus, mengurangi reabsorpsi asam empedu, meningkatkan fermentasi dan replikasi bakteri dalam usus, dan meningkatkan produksi SCFA (Ferrarese et al., 2018). Penelitian menunjukkan pemberian pisang dapat menurunkan kadar kolesterol total dan kadar trigliserida pada tikus pra sindroma metabolik (Hidayati \& Syauqy, 2015; Rusdaina \& Syauqy, 2015).

Kombinasi dari probiotik dan prebiotik disebut sinbiotik. Sinbiotik dibuat untuk meningkatkan daya hidup dari bakteri probiotik di saluran pencernaan (Pandey, Naik, \& Vakil, 2015), menstimulasi proliferasi strain bakteri yang ada di saluran pencernaan (Markowiak \& Śliżewska, 2017), dan meningkatkan produksi SCFA oleh bakteri probiotik dengan memfermentasi prebiotik (McLoughlin et al., 2017). Penelitian yang dilakukan Nurliyani et al., (2018) menunjukkan pemberian sinbiotik berupa kefir susu kambing yang ditambahkan prebiotik glukomanan dari umbi porang dapat menurunkan kadar kolesterol total dan kadar trigliserida pada tikus Sprague Dawley yang diberi High Fat Fructose Diet (HFFD). Penelitian ini dilakukan untuk membuktikan pengaruh sinbiotik dengan kefir tepung pisang batu (Musa balbisiana) terhadap kadar kolesterol total dan kadar trigliserida pada tikus model sindrom metabolik.

\section{METODE}

\section{Desain, Waktu, dan Tempat}

Penelitian ini dilakukan selama lima bulan dari Maret-Juli 2019 di Laboratorium Teknologi Pertanian dan Laboratorium Pusat Studi Pangan dan Gizi, Universitas Gadjah Mada. Penelitian ini menggunakan desain true experimental dengan rancangan pre-post test control group design. Rancangan ini menggunakan hewan coba yang dibagi secara acak menjadi empat kelompok, yaitu kelompok kontrol negatif $(\mathrm{K}-)$, kelompok kontrol positif $(\mathrm{K}+)$, kelompok perlakuan I (PI), dan kelompok perlakuan II (PII). Kelompok K-adalah tikus dalam kondisi sehat yang diberikan pakan standar. Kelompok $\mathrm{K}+$ adalah tikus model sindrom metabolik yang diberikan pakan standar. Kelompok PI dan kelompok PII adalah tikus model sindrom metabolik yang diberikan pakan standar dan sinbiotik kefir tepung pisang batu (Musa balbisiana). Penentuan dosis dilakukan melalui konversi dosis pada manusia seberat $70 \mathrm{~kg}$ sebanyak $100 \mathrm{ml}$ (Octavia, Djamiatun, \& Suci, 2017) dan $200 \mathrm{ml}$ (Moroti, Souza Magri, de Rezende Costa, Cavallini, \& Sivieri, 2012) 
sehingga didapatkan dosis tikus pada kelompok PI sebesar 1,8 ml/200grBB tikus/hari dan dosis tikus pada kelompok PII sebesar 3,6 ml/200grBB tikus/hari. Intervensi dilakukan selama 3 minggu. Pengambilan darah dilakukan pada awal dan akhir intervensi untuk menganalisis kadar kolesterol total dan kadar trigliserida.

\section{Populasi dan Sampel}

Populasi dalam penelitian ini adalah tikus Sprague Dawley jantan (subjek). Tikus Sprague Dawley dipilih karena lebih sensitif terhadap lipid dan lebih tahan terhadap perlakuan dibandingkan tikus galur wistar (Andini \& Ardiaria, 2016). Penentuan besar sampel menggunakan hewan coba yaitu setiap kelompok minimal 5 ekor (World Health Organization (WHO), 2000) dan ditambahkan kemungkinan drop out 20\%, sehingga digunakan 6 subjek untuk setiap kelompok. Teknik pengambilan sampel pada penelitian ini adalah probability sampling dengan metode simple random sampling. Kriteria inklusi subjek adalah 1) berat tubuh 150-200 gram pada usia 8-12 minggu; 2) jenis kelamin jantan; 3) kondisi sehat yang ditandai dengan tikus aktif bergerak. Adapun kriteria eksklusi adalah 1) tikus mengalami diare selama masa penelitian dan atau mengalami penurunan berat badan sebesar $10 \%$ atau lebih, dan 2) tikus mati selama masa penelitian.

\section{Persiapan Produk}

Persiapan produk berupa pembuatan produk sinbiotik kefir tepung pisang batu (Musa balbisiana) dilakukan melalui beberapa tahap, yaitu 1) penimbangan bahan susu skim kambing $(100 \mathrm{ml})$, starter bakteri (Lactobacillus lactis, Lactobacillus cremoris, Lactobacillus diacetylactis, Lactobacillus acidophilus dan lactic yeast) (0,5 gr), dan tepung pisang batu (Musa balbisiana) (8gr); 2) proses pasteurisasi susu skim kambing pada suhu $80^{\circ} \mathrm{C}$ selama 15 menit; 3) pencampuran tepung pisang batu dengan susu skim kambing yang sudah dipasteurisasi; 4) pendinginan sampai suhu $25^{\circ} \mathrm{C}$; 5) penambahan starter probiotik; 6) inokulasi pada suhu ruang $\left(25^{\circ} \mathrm{C}\right)$ selama 24 jam; dan 7) penyaringan starter probiotik. Produk sinbiotik kefir tepung pisang batu (Musa balbisiana) ini memiliki kandungan BAL sebesar 6,7 x 107 CFU/ml dengan kadar air 83,80\%, kadar lemak 0,26\%, kadar protein 3,37\%, kadar karbohidrat 11,21\%, kadar serat 0,83\%, viskositas 42,2 cP, dan pH 4,10 (Praba, 2019).

\section{Tahapan Penelitian}

Penelitian ini dilakukan melalui beberapa tahapan, yaitu 1) aklimatisasi subjek dengan pemberian pakan standar Comfeed AD II dan aquadest secara ad libitum; 2) pengkondisian sindrom metabolik dengan pemberian pakan HFFD (fruktosa murni $1 \mathrm{ml} / 200 \mathrm{gBB}$ tikus/hari, kuning telur bebek $1 \mathrm{ml} / 200 \mathrm{gBB}$ tikus/hari, dan minyak babi $2 \mathrm{ml} / 200 \mathrm{gBB}$ tikus/hari) selama 2 minggu (Octavia, Djamiatun, \& Suci, 2017). Metode pemberian HFFD ini dipilih karena memiliki 
patogenesis sindrom metabolik yang mirip dengan manusia (Zhuhua et al., 2015); 3) pemeriksaan kondisi sindrom metabolik subjek berupa kadar glukosa darah puasa (GDP), kadar trigliserida, dan kadar kolesterol bigh-density lipoprotein (HDL); 4) intervensi sinbiotik kefir tepung pisang batu selama 3 minggu; 5) pengukuran kadar kolesterol total dan kadar trigliserida subjek yang dilakukan dengan metode Cholesterol Oxidase-Peroxidase Aminoantipyrine Phenol (CHOD-PAP) dan Glycerol 3 Phosphate Oxidase- Phenol Amino Phenazone (GPO-PAP).

\section{Analisis Data}

Data hasil pengkondisian sindrom metabolik dianalisis dengan uji One-way Analysis of Variance (ANOVA) yang dilanjutkan dengan uji Post Hoc Bonferroni. Data hasil pengukuran kadar kolesterol total dan kadar trigliserida sebelum dan setelah intervensi dianalisis dengan uji Paired T-Test. Selain itu, pada setiap kelompok juga dilakukan perhitungan selisih kadar kolesterol total dan kadar trigliserida sebelum dan setelah intervensi sehingga didapatkan nilai perubahan dan persentasenya.

\section{Etik Penelitian}

Penelitian ini telah memperoleh Ethical Approval dari Komisi Etik Penelitian Kesehatan (KEPK) Universitas Pembangunan Nasional "Veteran" Jakarta Nomor: B/2078/VII/2019/KEPK.

\section{HASIL DAN PEMBAHASAN}

\section{Pengkondisian Sindrom Metabolik Subjek}

Uji normalitas dengan uji Saphiro-Wilk menunjukkan bahwa data berdistribusi normal ( $\mathrm{p}>0,05)$, sehingga mean (rerata) dan standar deviasi (SD) digunakan sebagai ukuran pemusatan dan penyebaran data. Selain itu, uji Homogenity of Variances menunjukkan bahwa varian data homogen, sehingga digunakan uji statistik parametrik One-Way ANOVA untuk mengetahui perbedaan rerata GDP, trigliserida, dan HDL antar kelompok. Selanjutnya, uji lanjutan Post Hoc Bonferroni digunakan untuk mengetahui letak perbedaan rerata GDP, trigliserida, dan HDL pada setiap kelompok. Hasil uji yang diperoleh dapat dilihat pada Tabel 1.

Hasil uji pada Tabel 1 menunjukkan bahwa terdapat perbedaan rerata GDP, trigliserida, dan HDL yang signifikan $(p=0,000)$ antar kelompok. Selain itu, rerata GDP, trigliserida, dan HDL antara kelompok K+, PI, dan PII dengan kelompok Kmenunjukkan adanya perbedaan yang signifikan $(\mathrm{p}<0,05)$. Rerata pada kelompok $\mathrm{K}-$ digunakan sebagai gambaran kadar GDP, trigliserida, dan HDL tikus normal. Rerata GDP subjek pada kelompok K+, PI, dan PII sudah melebihi rerata GDP kelompok $\mathrm{K}$-, sehingga subjek tersebut sudah mengalami hiperglikemia. Selain itu, rerata kadar trigliserida subjek pada kelompok K+, PI, dan PII sudah melebihi rerata trigliserida 
kelompok $\mathrm{K}-$, sehingga subjek juga sudah mengalami hipertrigliseridemia. Kelompok K+, PI, dan PII juga sudah memiliki kadar kolesterol HDL yang rendah karena berada dibawah rerata HDL pada kelompok K-. Dengan demikian, subjek pada kelompok K+, PI, dan PII telah mengalami hiperglikemia dan hipertrigliserida serta memiliki kadar kolesterol HDL rendah, dimana ketiganya merupakan kriteria dari sindrom metabolik.

Tabel 1. Rerata hasil pengkondisian sindrom metabolik subjek

\begin{tabular}{|c|c|c|c|c|}
\hline \multirow[b]{2}{*}{ Kelompok } & \multirow[b]{2}{*}{$\mathbf{n}$} & \multicolumn{3}{|c|}{ Kriteria \pm SD } \\
\hline & & GDP (mg/dl) & $\begin{array}{c}\text { Trigliserida } \\
\text { (mg/dl) }\end{array}$ & HDL (mg/dl) \\
\hline${ }^{1} \mathrm{~K}-$ & 6 & $71,02 \pm 1,80^{\mathrm{b}}$ & $67,60 \pm 3,92^{b}$ & $78,66 \pm 2,22^{b}$ \\
\hline${ }^{2} \mathrm{~K}+$ & 6 & $132,29 \pm 1,43^{* a}$ & $154,08 \pm 2,66 * a$ & $25,84 \pm 1,79 * a$ \\
\hline${ }^{2} \mathrm{PI}$ & 6 & $130,44 \pm 1,99 * a$ & $154,35 \pm 3,02 * a$ & $24,45 \pm 1,13^{* a}$ \\
\hline${ }^{2} \mathrm{PII}$ & 6 & $131,45 \pm 2,37 * a$ & $155,82 \pm 2,92 * a$ & $25,03 \pm 2,12 * a$ \\
\hline $\mathrm{P}$ & & 0,000 & 0,000 & 0,000 \\
\hline
\end{tabular}

${ }^{1}$ Kelompok yang tidak diberikan High Fat Fructose Diet, ${ }^{2}$ Kelompok yang diberikan High Fat Fructose Diet, *Kriteria sindrom metabolik (hiperglikemia, hipertrigliseridemia, dan kolesterol HDL yang rendah); a,b Notasi yang berbeda menunjukkan adanya perbedaan rerata yang signifikan pada uji lanjut Post Hoc Bonferroni

Hasil penelitian ini didukung oleh penelitian yang dilakukan oleh Crescenzo et al., (2014), dimana pemberian pakan tinggi lemak dan tinggi fruktosa dalam waktu pendek yaitu selama 2 minggu telah menunjukkan adanya gangguan homeostasis glukosa dan metabolisme lemak pada tikus jantan. Penelitian lainnya juga menunjukkan bahwa pemberian pakan HFFD selama 2 minggu meningkatkan kadar GDP dan kadar trigliserida serta menurunkan kadar kolesterol HDL pada tikus Wistar jantan (Rahmawati, Djamiatun, \& Suci, 2017).

Asupan fruktosa yang tinggi dapat meningkatkan kadar glukosa darah karena menyebabkan terganggunya sinyal insulin sehingga menurunkan sintesis glikogen dan meningkatkan glukoneogenesis (Rahmawati, Djamiatun, \& Suci, 2017). Peningkatan metabolisme fruktosa menyebabkan peningkatan produksi ATP sehingga akan mendorong peningkatan sintesis asam lemak (Gropper \& Smith, 2013). Asam lemak bebas ini kemudian akan dimobilisasi dari jaringan lemak menuju hati dan berikatan dengan gliserol membentuk trigliserida (Cahyani, 2017). Kondisi tersebut menyebabkan peningkatan ekskresi trigliserida menggunakan VLDL dari hati menuju jaringan dan organ melewati sirkulasi darah (Gropper \& Smith, 2013).

Pemberian pakan tinggi lemak seperti minyak babi dan kuning telur bebek pada tikus dapat meningkatkan kadar lemak di dalam darah sehingga menurunkan kemampuan reseptor insulin. Hal ini menyebabkan uptake glukosa ke dalam sel terganggu dan kadar glukosa dalam darah meningkat (Rahmawati, Djamiatun, \& Suci, 2017). Peningkatan kadar lemak dalam darah juga akan meningkatkan 
penyimpanan lemak berlebih di jaringan adiposa, meningkatkan aktivitas lipogenesis, dan meningkatkan produksi asam lemak bebas. Selain itu, kolesterol dalam sirkulasi darah juga akan meningkat sehingga hati akan mengeluarkan HDL untuk mengangkut kolesterol. Selanjutnya, HDL akan diesterifikasi menjadi ester kolesterol, dimana peningkatan ester kolesterol menyebabkan lipase hepatik memecah HDL sehingga kadar HDL di sirkulasi darah mengalami penurunan (Cahyani, 2017).

\section{Kadar Kolesterol Subjek Sebelum dan Setelah Intervensi}

Tabel 2 menunjukkan bahwa terdapat perbedaan rerata kadar kolesterol total yang signifikan sebelum dan setelah intervensi pada semua kelompok. Rerata perubahan kadar kolesterol total antara kelompok $\mathrm{K}$ - dan $\mathrm{K}+$ dengan kelompok PI dan PII menunjukkan hasil yang berbeda. Kelompok $\mathrm{K}$ - dan $\mathrm{K}+$ mengalami peningkatan rerata kadar kolesterol total, sementara kelompok PI dan PII mengalami penurunan.

Tabel 2. Rerata kadar kolesterol total sebelum dan setelah intervensi

\begin{tabular}{|c|c|c|c|c|c|c|}
\hline \multirow[t]{2}{*}{ Kelompok } & \multirow[t]{2}{*}{ n } & \multirow{2}{*}{$\begin{array}{c}\begin{array}{c}\text { Sebelum } \\
(\mathrm{mg} / \mathrm{dl})\end{array} \\
\text { Rerata } \pm \mathrm{SD}\end{array}$} & \multirow{2}{*}{$\begin{array}{c}\begin{array}{c}\text { Setelah } \\
(\mathrm{mg} / \mathrm{dl})\end{array} \\
\text { Rerata } \pm \mathrm{SD}\end{array}$} & \multirow[t]{2}{*}{$\mathrm{p}$} & \multicolumn{2}{|c|}{$\Delta$ Perubahan $(\mathrm{mg} / \mathrm{dl})$} \\
\hline & & & & & Rerata \pm SD & $\%$ \\
\hline${ }^{1} \mathrm{~K}-$ & 6 & $86,96 \pm 2,42$ & $88,57 \pm 2,05$ & $0,000^{*}$ & $1,61 \pm 0,47$ & 1,85 \\
\hline${ }^{1} \mathrm{~K}+$ & 6 & $219,56 \pm 4,13$ & $221,63 \pm 4,42$ & $0,007 *$ & $2,07 \pm 1,17$ & 0,94 \\
\hline $2 \mathrm{PI}$ & 6 & $217,72 \pm 7,37$ & $130,72 \pm 6,52$ & $0,000^{*}$ & $-87,01 \pm 10,94$ & $-39,96$ \\
\hline${ }^{2} \mathrm{PII}$ & 6 & $219,10 \pm 7,87$ & $106,06 \pm 1,54$ & $0,000^{*}$ & $-113,04 \pm 7,43$ & $-51,59$ \\
\hline
\end{tabular}

${ }^{1}$ Kelompok yang tidak diberikan sinbiotik kefir tepung pisang batu; ${ }^{2}$ Kelompok yang diberikan sinbiotik kefir tepung pisang batu; *Signifikansi hasil uji Paired T-Test

Hasil ini menunjukkan bahwa rerata kadar kolesterol total pada kelompok PI dan PII mengalami penurunan secara signifikan $(p=0,000)$ setelah diberikan sinbiotik kefir tepung pisang batu. Sinbiotik kefir tepung pisang batu yang diberikan dalam penelitian ini mengandung BAL sebanyak 6,7 x $10^{7} \mathrm{cfu} / \mathrm{ml}$ (Praba, 2019). Penelitian yang dilakukan Saputra \& Margawati (2015) menunjukkan bahwa pemberian yoghurt sinbiotik tanpa lemak dengan penambahan tepung gembili yang memiliki kandungan BAL $7 \pm 6,52 \times 10^{7} \mathrm{cfu} / \mathrm{ml}$ dapat menurunkan kadar kolesterol total secara signifikan pada tikus hiperkolesterolemia. Hasil ini juga didukung oleh penelitian yang memberikan sinbiotik berupa kefir susu kambing dengan penambahan glukomanan dari porang sebagai prebiotik yang terbukti dapat menurunkan kadar kolesterol total pada tikus Sprague Dawley yang diberi HFFD (Nurliyani et al., 2018). Hasil penelitian yang dilakukan oleh Hardiansyah, (2020) menunjukkan bahwa kadar lemak di dalam kefir susu kambing sebanyak 2,02\% (2,02 gram/100 gram) yang berarti nilai tersebut sesuai standar codex susu fermentasi yaitu kurang dari 10\%. Penurunan kadar kolesterol total dalam penelitian ini terjadi 
pada kelompok PI dan PII, yaitu kelompok yang diberikan sinbiotik kefir tepung pisang batu.

Mekanisme penurunan kolesterol total oleh probiotik dapat terjadi dengan mengikat dan memasukkan kolesterol ke dalam membran sel probiotik sehingga mengurangi penyerapan kolesterol dalam usus. Beberapa dari bakteri probiotik dapat mengasimilasi kolesterol secara langsung dari saluran pencernaan. Selain itu, probiotik dapat mengurangi sirkulasi enterohepatik dari asam empedu karena adanya aktivitas hidrolase yang mengkatalis proses hidrolisis dekonjugasi asam empedu (Cho \& Kim, 2015). Bakteri dalam usus mendekonjugasi asam empedu menjadi asam empedu sekunder sehingga tidak dapat diabsorbsi kembali untuk masuk ke dalam sirkulasi enterohepatik, tetapi akan dibuang melalui feses. Peningkatan ekskresi dari asam empedu ini akan menurunkan sirkulasi enterohepatik oleh garam empedu sehingga menyebabkan tubuh menggunakan kolesterol untuk mensintesis asam empedu yang baru. Kolesterol yang digunakan untuk membuat lebih banyak asam empedu dapat mengurangi konsentrasi kolesterol di dalam tubuh (Gropper \& Smith, 2013).

Penambahan prebiotik efektif dalam meningkatkan populasi bakteri dalam usus, karena prebiotik bertindak sebagai substrat untuk pertumbuhan dan aktivitas bakteri tertentu (Gropper \& Smith, 2013). Selain itu, prebiotik dapat meningkatkan viskositas usus sehingga mengganggu uptake kolesterol dari makanan dan mengurangi reabsorbsi asam empedu (menurunkan sirkulasi enterohepatik). Prebiotik juga akan difermentasi oleh bakteri dalam kolon sehingga menghasilkan SCFA (McLoughlin et al., 2017). SCFA yang diproduksi oleh bakteri probiotik dapat menghambat sintesis kolesterol hati dan redistribusi kolesterol dari plasma ke hati (Cho \& Kim, 2015). Jenis asam lemak tersebut dapat meningkatkan rasio molar propionat terhadap asetat (Ferrarese et al., 2018) dan menurunkan sintesis asam lemak pada hepatosit (Weitkunat et al., 2015). Asam propionat terabsorbi yang dihasilkan oleh fermentasi prebiotik oleh probiotik juga dapat menghambat sintesis kolesterol di hati sehingga memiliki efek hipokolesterolemia (Gropper \& Smith, 2013).

\section{Kadar Trigliserida Subjek Sebelum dan Setelah Intervensi}

Hasil analisis kadar trigliserida menunjukkan bahwa terdapat perbedaan rerata kadar trigliserida yang signifikan pada semua kelompok antara sebelum dan setelah intervensi (Tabel 3). Hasil yang berbeda ditunjukkan pada rerata perubahan kadar trigliserida sebelum dan setelah intervensi antara kelompok $\mathrm{K}$ - dan $\mathrm{K}+$ dengan kelompok PI dan PII. Terjadi peningkatan kadar trigliserida pada kelompok $\mathrm{K}$ - dan $\mathrm{K}+$. Sebaliknya, terjadi penurunan rerata kadar trigliserida pada kelompok PI dan PII. 
Rerata kadar trigliserida pada kelompok PI dan PII dalam penelitian ini juga menunjukkan penurunan yang signifikan setelah pemberian sinbiotik kefir tepung pisang batu. Kelompok PII yang diberikan sinbiotik kefir tepung pisang batu sebanyak 3,6 ml/200grBB tikus/hari mengalami penurunan kadar trigliserida yang lebih besar dibandingkan kelompok PI yang diberikan 1,8 ml/200grBB tikus/hari. Hasil penelitian sebelumnya menunjukkan bahwa kandungan BAL sebanyak $7 \pm$ $6.52 \times 10^{7} \mathrm{cfu} / \mathrm{ml}$ dalam yoghurt sinbiotik tanpa lemak dengan penambahan tepung gembili telah menunjukkan penurunan kadar trigliserida yang signifikan pada tikus hiperkolesterolemia (Febriansyah \& Pramono, 2015). Pada penelitian lain, Nurliyani et al., (2018) juga menyatakan bahwa pemberian sinbiotik berupa kefir susu kambing yang ditambahkan glukomanan porang sebagai prebiotik dapat menurunkan kadar trigliserida pada tikus Sprague Dawley yang diberi HFFD.

Tabel 3. Rerata kadar trigliserida sebelum dan setelah intervensi

\begin{tabular}{|c|c|c|c|c|c|c|}
\hline \multirow{2}{*}{ Kelompok } & \multirow{2}{*}{$\mathbf{n}$} & \multirow{2}{*}{$\begin{array}{c}\begin{array}{c}\text { Sebelum } \\
(\mathrm{mg} / \mathrm{dl})\end{array} \\
\text { Rerata } \pm \mathrm{SD}\end{array}$} & \multirow{2}{*}{$\begin{array}{c}\begin{array}{c}\text { Sesudah } \\
(\mathrm{mg} / \mathrm{dl})\end{array} \\
\text { Rerata } \pm \mathrm{SD}\end{array}$} & \multirow{2}{*}{$\mathrm{p}$} & \multicolumn{2}{|c|}{$\Delta$ Perubahan $(\mathrm{mg} / \mathrm{dl})$} \\
\hline & & & & & Rerata \pm SD & $\%$ \\
\hline${ }^{1} \mathrm{~K}-$ & 6 & $67,60 \pm 3,92$ & $69,54 \pm 4,06$ & $0,003 *$ & $1,93 \pm 0,85$ & 2,86 \\
\hline${ }^{1} \mathrm{~K}+$ & 6 & $154,08 \pm 2,66$ & $156,80 \pm 2,98$ & $0,000^{*}$ & $2,72 \pm 0,70$ & 1,77 \\
\hline 2PI & 6 & $154,35 \pm 3,02$ & $104,74 \pm 4,58$ & $0,000^{*}$ & $-49,61 \pm 4,88$ & $-32,14$ \\
\hline${ }^{2} \mathrm{PII}$ & 6 & $155,82 \pm 2,92$ & $94,01 \pm 3,02$ & $0,000 *$ & $-61,81 \pm 5,20$ & $-39,67$ \\
\hline
\end{tabular}

${ }^{1}$ Kelompok yang tidak diberikan sinbiotik kefir tepung pisang batu; ${ }^{2}$ Kelompok yang diberikan sinbiotik kefir tepung pisang batu; * Signifikansi hasil uji Paired T-Test

Penurunan kadar trigliserida pada penelitian ini terjadi pada kelompok yang diberikan sinbiotik kefir tepung pisang batu. Sinbiotik kefir tepung pisang batu mengandung bakteri probiotik serta pati resisten, FOS, dan juga inulin yang berperan sebagai prebiotik. Sinbiotik merupakan kombinasi dari probiotik dan prebiotik (Rahmawati, Djamiatun, \& Suci, 2017). Sinbiotik dibuat untuk mengatasi beberapa kemungkinan kesulitan dalam kelangsungan hidup probiotik di saluran pencernaan (Markowiak \& Śliżewska, 2017), sehingga penambahan prebiotik mampu meningkatkan daya hidup dari probiotik (Pandey et al., 2015). Prebiotik dapat difermentasi di dalam usus oleh bakteri probiotik sehingga menghasilkan SCFA (McLoughlin et al., 2017). SCFA seperti propionat dapat menghambat pengambilan asetat dan menekan sintesis asam lemak dalam hati (Weitkunat et al., 2015). Pengaturan biosintesis trigliserida didorong oleh keberadaan asam lemak, sehingga penurunan sintesis asam lemak di hati dapat menurunkan sintesis trigliserida di dalam tubuh (Gropper \& Smith, 2013). 


\section{KESIMPULAN}

Terdapat perbedaan kadar kolesterol total dan kadar trigliserida sebelum dan setelah pemberian sinbiotik kefir tepung pisang batu (Musa balbisiana) pada tikus model sindrom metabolik. Penurunan kadar kolesterol total dan kadar trigliserida terbesar terjadi pada dosis pemberian sinbiotik kefir tepung pisang batu (Musa balbisiana) 3,6 ml/200grBB tikus/hari.

\section{DAFTAR PUSTAKA}

Ahmed, A. S., El-Bassiony, T., Elmalt, L. M., \& Ibrahim, H. R. (2015). Identification of potent antioxidant bioactive peptides from goat milk proteins. Food Research International, 74, 80-88. https://doi.org/10.1016/j.foodres.2015.04.032

Andini, A. N., \& Ardiaria, M. (2016). Pengaruh pemberian kombinasi minyak rami dengan minyak wijen terhadap kadar trigliserida pada tikus sprague dawley dislipidemia. Journal of Nutrition College, 5(4), 555-564. https://doi.org/10.14710/jnc.v5i4.16472

Blesso, C. N., \& Fernandez, M. L. (2018). Dietary cholesterol, serum lipids, and heart disease: are eggs working for or against you? Nutrients, 10(426), 1-12. https://doi.org/10.3390/nu10040426

Bourrie, B. C. T., Willing, B. P., \& Cotter, P. D. (2016). The Microbiota and Health Promoting Characteristics of the Fermented Beverage Kefir. Frontiers in Microbiology, 7(647), 1-17. https://doi.org/10.3389/fmicb.2016.00647

Cahyani, T. D. A. (2017). Pengaruh yoghurt dan soyghurt herbal sinbiotik jelly drink ekstrak jahe merah (zingiber officinale var. rubrum) terhadap kadar malondialdehid (mda) tikus pra-sindrom metabolik. Universitas Diponegoro, Semarang.

Carasi, P., Racedo, S. M., Jacquot, C., Romanin, D. E., Serradell, M. A., \& Urdaci, M. C. (2015). Impact of kefir derived lactobacillus kefiri on the mucosal immune response and gut microbiota. Journal of Immunology Research, 2015, 112. https:/ / doi.org/10.1155/2015/361604

Chen, C.-Y., Lee, C.-W., Chien, S.-C., Su, M.-I., Lin, S.-I., Cheng, C.-W., ... Yeh, H.-I. (2018). Dyslipidemia management for elderly people with metabolic syndrome: A mini-review. International Journal of Gerontology, 12(1), 7-11. https://doi.org/10.1016/j.ijge.2017.07.001

Cho, Y. A., \& Kim, J. (2015). Effect of probiotics on blood lipid concentrations: A meta-analysis of randomized controlled trials. Medicine, 94(43), 1-10. https://doi.org/10.1097/MD.0000000000001714

Crescenzo, R., Bianco, F., Coppola, P., Mazzoli, A., Tussellino, M., Carotenuto, R., ... Iossa, S. (2014). Fructose supplementation worsens the deleterious effects of short-term high-fat feeding on hepatic steatosis and lipid metabolism in adult rats. Experimental Physiology, 99(9), 1203-1213. https://doi.org/10.1113/expphysiol.2014.079632

Febriansyah, R., \& Pramono, A. (2015). Pengaruh pemberian yoghurt sinbiotik tanpa lemak dengan penambahan tepung gembili terhadap kadar trigliserida tikus hiperkolesterolemia. Journal of Nutrition College, 4(1), 57-61. 
https:/ / doi.org/10.14710/jnc.v4i1.8621

Ferrarese, R., Ceresola, E. R., Preti, A., \& Canducc, F. (2018). Probiotics, prebiotics and synbiotics for weight loss and metabolic syndromein the microbiome era. European Review for Medical and Pharmacological Sciences, 22, 7588-7605. https://doi.org/10.26355/eurrev_201811_16301

García, V., Rovira, S., Boutoial, K., \& López, M. B. (2014). Improvements in goat milk quality: A review. Small Ruminant Research, 121(1), 51-57. https://doi.org/10.1016/j.smallrumres.2013.12.034

Gropper, S. S., \& Smith, Jack L. (2013). Nutrition and human metabolism (6th ed.). USA: Wadsworth.

Hardiansyah, A. (2020). IDENTIFIKASI NILAI GIZI DAN POTENSI MANFAAT KEFIR SUSU KAMBING KALIGESING. Journal of Nutrition College, 9(3), 208-214.

Hardisari, R., \& Amaliawati, N. (2016). Manfaat Prebiotik Tepung Pisang Kepok (Musa paradisiaca formatypica) terhadap Pertumbuhan Probiotik Lactobacillus casei secara In Vitro. Jurnal Teknologi Laboratorium, 5(2), 64-67.

Hidayati, S. N., \& Syauqy, A. (2015). Pengaruh pemberian pisang kepok (musa paradisiacal forma typical) terhadap kadar kolesterol total tikus sprague dawley pra sindrom metabolik. Journal of Nutrition College, 4(4), 499-507. https://doi.org/10.14710/jnc.v4i4.10154

Markowiak, P., \& Śliżewska, K. (2017). Effects of probiotics, prebiotics, and synbiotics on human health. Nutrients, 1021(9), 1-30. https://doi.org/10.3390/nu9091021

Mazidi, M., Pennathur, S., \& Afshinnia, F. (2017). Link of dietary patterns with metabolic syndrome: Analysis of the national health and nutrition examination survey. Nutrition \& Diabetes, 7(3), 1-8. https://doi.org/10.1038/nutd.2017.11

McLoughlin, R. F., Berthon, B. S., Jensen, M. E., Baines, K. J., \& Wood, L. G. (2017). Short-chain fatty acids, prebiotics, synbiotics, and systemic inflammation: A systematic review and meta-analysis. The American Journal of Clinical Nutrition, 106(3), 930-945. https://doi.org/10.3945/ajcn.117.156265

Moroti, C., Souza Magri, L., de Rezende Costa, M., Cavallini, D. C., \& Sivieri, K. (2012). Effect of the consumption of a new symbiotic shake on glycemia and cholesterol levels in elderly people with type 2 diabetes mellitus. Lipids in Health and Disease, 11(29), 1-8. https://doi.org/10.1186/1476-511X-11-29

Mukaromah, A. S., \& Susilowati, F. (2021). Tropical Herbs and Spices as Functional Foods with Antidiabetic activity. USA: Apple Academic Press.

Musita, N. (2014). Pemanfaatan tepung pisang batu (musa balbisiana colla) pada pembuatan kue brownies. Indonesian Journal of Industrial Research, 8(3), 171-178.

Nolan, P. B., Carrick-Ranson, G., Stinear, J. W., Reading, S. A., \& Dalleck, L. C. (2017). Prevalence of metabolic syndrome and metabolic syndrome components in young adults: A pooled analysis. Preventive Medicine Reports, 7, 211-215. https://doi.org/10.1016/j.pmedr.2017.07.004

Nova, M., \& Yanti, R. (2017). Faktor-faktor yang berhubungan dengan obesitas pada orang dewasa di Kota Padang Panjang. Nutri-Sains: Jurnal Gizi, Pangan Dan Aplikasinya, 1(1), 12-21. 
Nurliyani, Harmayani, E., \& Sunarti. (2018). Goat milk kefir supplemented with porang glucomannan improves lipid profile and haematological parameter in rat fed high fat and high fructose diet. Romanian Journal of Diabetes Nutrition and Metabolic Diseases, 25(1), 11-21. https://doi.org/10.2478/rjdnmd-2018-0002

Octavia, Z. F., Djamiatun, K., \& Suci, N. (2017). Pengaruh pemberian yogurt sinbiotik tepung pisang tanduk terhadap profil lipid tikus sindrom metabolik. Jurnal Gizi Klinik Indonesia, 13(4), 159-169. https://doi.org/10.22146/ijcn.19369

Pandey, K. R., Naik, S. R., \& Vakil, B. V. (2015). Probiotics, prebiotics and synbiotics- a review. Journal of Food Science and Technology, 52(12), 7577-7587. https://doi.org/10.1007/s13197-015-1921-1

Pimenta, F. S., Luaces-Regueira, M., Ton, A. M., Campagnaro, B. P., CamposToimil, M., Pereira, T. M., \& Vasquez, E. C. (2018). Mechanisms of action of kefir in chronic cardiovascular and metabolic diseases. Cellular Physiology and Biochemistry, 48(5), 1901-1914. https:/ / doi.org/10.1159/000492511

Praba, S. K. (2019). Formulasi kefir susu kambing dengan penambahan tepung pisang batu (musa balbisiana) sebagai minuman sinbiotik. Universitas Pembangunan Nasional Veteran Jakarta, Jakarta.

Rahmawati, F. C., Djamiatun, K., \& Suci, N. (2017). Pengaruh yogurt sinbiotik pisang terhadap kadar glukosa dan insulin tikus sindrom metabolik. Jurnal Gizi Klinik Indonesia, 14(1), 11-21. https://doi.org/10.22146/ijcn.19379

Razmpoosh, E., Javadi, A., Ejtahed, H. S., Mirmiran, P., Javadi, M., \& Yousefinejad, A. (2019). The effect of probiotic supplementation on glycemic control and lipid profile in patients with type 2 diabetes: A randomized placebo controlled trial. Diabetes \& Metabolic Syndrome: Clinical Research \& Reviews, 13(1), 175-182. https://doi.org/10.1016/j.dsx.2018.08.008

Rosa, D. D., Dias, M. M. S., Grześkowiak, Ł. M., Reis, S. A., Conceição, L. L., \& Peluzio, M. do C. G. (2017). Milk kefir: Nutritional, microbiological and health benefits. Nutrition Research Reviews, 30(1), 82-96. https://doi.org/10.1017/S0954422416000275

Rusdaina, R., \& Syauqy, A. (2015). Pengaruh pemberian pisang kepok (musa paradisiaca forma typical) terhadap kadar trigliserida tikus sprague dawley pra sindrom metabolik. Journal of Nutrition College, 4(4), 585-592. https://doi.org/10.14710/jnc.v4i4.10166

Saklayen, M. G. (2018). The global epidemic of the metabolic syndrome. Current Hypertension Reports, 20(2), 1-8. https://doi.org/10.1007/s11906-018-0812-z

Saputra, S., \& Margawati, A. (2015). Pengaruh pemberian yoghurt sinbiotik tanpa lemak dengan penambahan tepung gembili (dioscorea esculenta) terhadap kadar kolesterol total tikus hiperkolesterolemia. Journal of Nutrition College, 4(2), 104-109. https://doi.org/10.14710/jnc.v4i2.10052

Singh, A., \& Singh, R. (2016). Triglyceride and cardiovascular risk: A critical appraisal. Indian Journal of Endocrinology and Metabolism, 20(4), 418-428. https://doi.org/10.4103/2230-8210.183460

Soewondo, P., Purnamasari, D., Oemardi, M., Waspadji, S., \& Soegondo, S. (2010). Prevalence of metabolic syndrome using NCEP/ATP III criteria in Jakarta, 
Indonesia: the Jakarta primary non-communicable disease risk factors surveillance 2006. Acta Medica Indonesiana, 42(4), 199-203.

Syagata, A. (2019). Risiko Tinggi Diabetes Mellitus Tipe 2 pada Pegawai Usia Dewasa (High Risk of Type 2 Diabetes Mellitus among Working Adult). 3, 52-59.

Weitkunat, K., Schumann, S., Petzke, K. J., Blaut, M., Loh, G., \& Klaus, S. (2015). Effects of dietary inulin on bacterial growth, short-chain fatty acid production and hepatic lipid metabolism in gnotobiotic mice. The Journal of Nutritional Biochemistry, 26(9), 929-937. https://doi.org/10.1016/j.jnutbio.2015.03.010

World Health Organization (WHO). (2000). General guidelines for methodologies on research and evaluation of traditional medicine. Geneva: World Health Organization (WHO).

Wu, Y., Zhang, Q., Ren, Y., \& Ruan, Z. (2017). Effect of probiotic Lactobacillus on lipid profile: A systematic review and meta-analysis of randomized, controlled trials. PLOS ONE, 12(6), 1-15. https://doi.org/10.1371/journal.pone.0178868

Zhang, A., Yao, Y., Xue, Z., Guo, X., Dou, J., Lv, Y., ... Jin, L. (2018). A study on the factors influencing triglyceride levels among adults in Northeast China. Scientific Reports, 8(1), 1-7. https://doi.org/10.1038/s41598-018-24230-4

Zhuhua, Z., Zhiquan, W., Zhen, Y., Yixin, N., Weiwei, Z., Xiaoyong, L., ... Qing, S. (2015). A novel mice model of metabolic syndrome: the high-fat-high-fructose diet-fed ICR mice. Experimental Animals, 64(4), 435-442. https://doi.org/10.1538/expanim.14-0086 
Halaman ini sengaja dikosongkan. 